\title{
BIOMONITORING: \\ SEBAGAI ALAT ASESMEN KUALITAS PERAIRAN AKIBAT LOGAM BERAT KADMIUM PADA INVERTEBRATA PERAIRAN
}

\author{
Dominggus Rumahlatu \\ Universitas Pattimura, J1. Dr.Tamaela Ambon \\ E-mail: dominggus_amq@yahoo.co.id
}

\begin{abstract}
People's activity in water area has made this area as waste place from a variety of human's activity. One contaminant thrown to the seaboard is heavy metal, specifically for cadmium $(C d)$. Naturally, the pollution sources of heavy metal Cd in water area are coming from geological process and some of human's activity (antropogenic). The effect of Cd's contamination to invertebrate water are died effect and ecology's unbalancing of sea organism varieties. It is because Cd cannot be broken up (non degradable) by living organism and it can be accumulated to the environment. One effort to tackling heavy metal $\mathrm{Cd}$ contamination in water is doing biomonitoring accumulation as assessment instrument of water quality.
\end{abstract}

Key words: biomonitoring, biomoitoring accumulation, heavy metal Cadmium, invertebrate water

\section{PENDAHULUAN}

Aktifitas masyarakat seperti kegiatan perikanan (tangkap dan budidaya), industry, dan pariwisata menyebabkan banyak bahan pencemar yang masuk ke dalam perairan. Pencemaran perairan ditandai dengan adanya perubahan sifat fisik, kimia dan biologi perairan. Bahan pencemar berupa logam berat di perairan akan membahayakan kehidupan organisme, maupun efeknya secara tidak langsung terhadap kesehatan manusia. Salah satu jenis logam berat yang memasuki perairan dan bersifat toksik adalah kadmium (Cd).
Cd merupakan logam berat yang sangat berbahaya karena tidak dapat dihancurkan (non degradable) oleh organisme hidup dan dapat terakumulasi ke lingkungan, terutama mengendap di dasar perairan membentuk senyawa kompleks bersama bahan organik dan anorganik secara adsorbsi dan kombinasi (Rochyatun dan Rozak, 2007; Ayeni et al., 2010). Gbaruko dan Friday (2007) menjelaskan bahwa logam berat $\mathrm{Cd}$ secara alami merupakan komponen yang terdapat pada lapisan bumi dan dapat memasuki perairan melalui rangkaian proses geokimia dan aktivitas manusia (antropogenik). Dijelaskan oleh Zhou et al., 2008; Shah, 
2005; Pal et al., 2006 bahwa, aktivitas manusia (antropogenik) merupakan penyebab utama kontaminasi logam berat $\mathrm{Cd}$ pada lingkungan perairan dan menyebabkan gangguan pada sistem biologis karena dapat terakumulasi dengan mudah dalam sedimen maupun organism.

Zhou et al. (2008) menjelaskan bahwa biomonitoring meliputi analisis terhadap bioakumulasi, biotoksisitas, dan biomarker. Perkembangan penelitian dalam bidang ekotoksikologi telah memunculkan pendekatan baru dalam mendeteksi keberadaan logam berat di perairan yaitu biomarker. Pendekatan biomarker memanfaatkan sistem biomolekuler yaitu sistem di bawah organisasi individu berupa molekul-molekul yang berupa enzim maupun protein yang disekresikan oleh organisme perairan sebagai respons terhadap keberadaan logam berat (Ayeni et al., 2010). Hal tersebut didasarkan pada asumsi bahwa ketika terjadi akumulasi logam berat di dalam sel maka sistem biomolekuler akan merespons dengan melakukan detoksifikasi atau asimilasi yang memungkinkan untuk proses homeostasis (Schoettger, 1996). Dijelaskan lebih lanjut oleh Schoettger
(1996) bahwa respons yang timbul pada organisasi seluler memang diperlukan untuk memastikan keberadaan logam berat di lingkungan. Russo et al. (2003) menjelaskan bahwa invertebrata laut memiliki sensivitas yang tinggi terhadap tekanan (stressor) logam berat dan memiliki kemampuan untuk merespons kontaminasi logam berat. Dengan memperhatikan efek toksik logam berat $\mathrm{Cd}$, maka upaya pengendalian dapat dilakukan dengan menentukan indikator biologis (bioindikator) sekaligus juga dapat berfungsi sebagai biomonitoring akumulasi pencemaran logam berat $\mathrm{Cd}$ di lingkungan perairan. Dengan demikian perlu dilakukan suatu kajian terkait dengan peluang suatu organisme digunakan sebagai alat biomonitoring akumulasi logam berat $\mathrm{Cd}$ di perairan.

Dalam makalah ini diuraikan hal-hal pokok: (1) sumber pencemaran logam berat kadmium dan efeknya terhadap invertebrata perairan: a) sifat dan sumber pencemaran logam berat kadmium, (b) efek toksik logam berat bagi invertebrata perairan, c) mekanisme absorpsi dan toksisitas logam berat kadmium di perairan; (2) biomonitoring logam berat sebagai alat asesmen kualitas perairan: a) pengertian biomonitoring, b) mengapa harus 
menggunakan biomonitoring, dan c) ruang lingkup dan teknik-teknik biomonitoring.

\section{BAHAN DAN METODE}

\section{Sumber Pencemaran Logam Berat}

Kadmium Dan Efeknya Terhadap

\section{Invertebrata Perairan}

Selama beberapa dekade terakhir ini, perhatian intensif diarahkan untuk mengatasi masalah kontaminasi logam berat pada lingkungan (Kortba et al., 1999; Zhou, 2008). Sebagian besar logam diketahui bersifat toksik atau racun dan sebagian diantaranya dilepaskan ke lingkungan dalam jumlah yang dapat menimbulkan resiko pada kesehatan manusia (El-said \& Garamon, 2010). Istilah logam sering dideskripsikan atau dibedakan dari non logam karena karakteristik fisikanya sebagai penghantar panas dan listrik (Appenroth, 2010). Dijelaskan lebih lanjut oleh Duruibe et al. (2007) bahwa istilah logam berat merujuk pada elemen logam yang memiliki kepadatan yang tinggi dan bersifat toksik atau racun bahkan pada konsentrasi yang rendah. Sejalan dengan itu, Schurtzendubel \& Polle (2002) juga menambahkan bahwa logam berat dapat didefenisikan sebagai logam dengan kepadatan yang lebih dari $5 \mathrm{~g} / \mathrm{cm}^{-3}$. Flora (2009) mendefinisikan logam berat sebagai kelompok logam yang umumnya merupakan logam transisi yaitu yang termasuk dalam golongan lantanida dan aktanida. Appenroth (2010) menjelaskan bahwa karakteristik kimia suatu elemen dapat ditentukan berdasarkan posisinya pada tabel sistem periodik. Dijelaskan lebih lanjut bahwa umumnya, elemen yang berada pada bagian bawah sebelah kiri tabel sistem periodik menunjukkan bahwa elemenelemen tersebut semakin bersifat logam, dan sebaliknya jika berada pada bagian kanan atas menunjukkan bahwa elemenelemen tersebut merupakan elemen non logam. Pendapat yang lain diberikan oleh Choudhury \& Panda (2004) bahwa yang termasuk dalam kategori logam berat adalah elemen-elemen yang termasuk dalam golongan logam nonesensial bagi makhluk hidup. Berdasarkan sifat kelarutannya, terdapat 17 jenis logam berat yang termasuk dalam logam berat esensial yang dibutuhkan oleh organisme dan ekosistem (Schutzendubel \& Polle, 2002).

Logam berat merupakan komponen alami yang terdapat pada kulit bumi dan dapat memasuki 
ekosistem perairan dan rantai makanan melalui proses geokimia (Gbaruko \& Friday, 2007; Zhou, 2008). Dijelakan lebih lanjut oleh Flora (2009) bahwa secara alami, logam merupakan komponen yang menyusun ekosistem, terdapat pada atmosfer, hidrosfer dan biosfer. Selain merupakan komponen alami kulit bumi, sumber kontaminasi logam berat lainnya adalah berasal dari aktivitas manusia (antropogenik) seperti areal pertanian, industri dan perhubungan (Ayeni, 2010; Scoetgher, 1996; Miranda et al., 2004; Amisah et al., 2009; Yi et al., 2007).

\section{Sifat dan Sumber Pencemaran Logam Berat Kadmium}

Kadmium merupakan elemen ke-48 dan merupakan anggota dari kelompok 12 pada sistem tabel periodik. Umumnya, jenis kadmium yang teroksidasi di alam adalah $\mathrm{Cd}^{+2}$ (Flora et $a l .$, 2008). Dibandingkan dengan jenis logam berat lainnya, kadmium merupakan salah jenis logam berat yang memiliki toksisitas yang tinggi, penyebaran yang luas serta memiliki waktu paruh (biological life) yang panjang dalam tubuh organisme hidup yaitu sekitar 10-30 tahun karena tidak dapat didegradasi (Patrick, 2003; de Michele et al., 2009; Maria et al., 2006;
Agnello et al., 2007; Rico et al., 2002; Ohta et al., 2000; Flora et al., 2008; Krichah et al., 2003), memiliki sebaran pada areal yang sangat luas (Olivi et al., 2001), dan menimbulkan toksisitas yang tinggi bagi hewan dan tumbuhan (Schutzendubel et al., 2001) serta jika terabsorbsi ke dalam tubuh manusia, dapat menimbulkan ganggungan kesehatan yang serius (Cohen et al., 1998). Pada lingkungan perairan, kadmium secara cepat terdeposit pada organisme perairan dalam bentuk ionion bebas $\left(\mathrm{Cd}^{2+}\right)$ (Nordic, 2003). Dilaporkan oleh Kaneta et al. (1986) efek toksik logam berat jenis kadmium pada manusia pertama kali terjadi di Jepang pada tahun 1950 melalui beras yang terkontaminasi.

Terdapat dua sumber utama kontaminasi logam berat kadmium pada lingkungan yaitu melalui lapisan bumi dan aktivitas manusia (antropogenik) (Nordic, 2003). Secara alami, kadmium merupakan unsur utama fosfat bebatuan dan terdeposit dalam lapisan bumi. Selain merupakan komponen utama dari lapisan kulit bumi, sumber utama kadmium lainnya adalah industri panas bumi, industri bahan bangunan, areal pertambangan, industri logam dll (Maanan, 2007; Schutzendubel et al., 
2001). Logam berat kadmium sering digunakan sebagai pewarna cat dan plastik, sebagai katoda nikel, baterai dan alat elektronik lainnya (Yon et al., 2008) sehingga disimpulkan oleh Ruso et al. (2003) bahwa sumber utama kontaminasi logam berat jenis kadmium adalah daerah industri. Bukti bahwa logam berat kadmium memiliki sebaran kontaminasi yang luas pada lingkungan perairan dijelaskan oleh Patrick (2003), bahwa komisi perlindungan lingkungan Amerika (Environmetal Protection Agency) menyatakan bahwa logam berat jenis kadmium memiliki sebaran polusi yang sangat luas karena terdeteksi pada 776 dari 1.467 situs pengamatan di Amerika Serikat. Dijelaskan lebih lanjut bahwa logam berat kadmium dimasukan ke dalam daftar jenis logam berat yang sangat diwaspadai penyebaran dan toksisitasnya. Ololade \& Olongundudu (2007) menjelaskan bahwa rata-rata produksi kadmium di seluruh dunia meningkat dari hanya 20 ton pada tahun 1920 menjadi sekitar 12.000 ton pada periode tahun 1960-1969, 17 ton pada tahun 1970-1984 dan sejak tahun 1987 mengalami peningkatan fluktuasi menjadi 20.000 ton. Peningkatan produksi atau emisi logam berat kadmium pada lingkungan disebabkan karena tingkat penggunaannya yang luas pada berbagai jenis industri modern seperti elektronik, komunikasi, pembangkit energi dan industri luar angkasa (Ololade \& Ologundudu, 2007).

\section{Efek Toksik Logam Berat Bagi Invertebrata Perairan}

Kontaminasi logam berat pada lingkungan perairan, termasuk ekosistem laut, telah menjadi masalah hampir di seluruh dunia (Almeida et al., 2009). Dampak kontaminasi logam berat di ekosistem perairan pun telah banyak menjadi objek penelitian. Dijelaskan oleh Vinodhini \& Narayanan (2009) bahwa ekosistem perairan laut merupakan tempat utama kontaminasi logam berat yang dihasilkan oleh industri, areal pertanian dan saluran limbah rumah tangga. Sementara itu, menurut Maanan (2007), faktor-faktor yang mempengaruhi konsentrasi logam dan tingkat akumulasinya oleh organisme hidup adalah ketersiadaan logam berat di lingkungan, musim, hidrodinamik lingkungan, ukuran, jenis kelamin, perubahan komposisi jaringan dan siklus reproduksi. Sharma \& Prasad (2010) menjelaskan bahwa sebagian besar logam berat yang memasuki lingkungan perairan akan terendap di 
dalam sedimen dan dapat berpindah ke matriks lingkungan lainnya.

Jonak et al. (2004) menjelaskan bahwa logam berat memegang peran penting dalam proses fisilogis mahkluk hidup. Dalam konsentrasi yang rendah, beberapa ion logam berat dibutuhkan untuk proses metabolisme, pertumbuhan dan perkembangan. Hal ini disebabkan karena logam esensial merupakan komponen integral dan fungsional dari beberapa enzim dan berperan penting dalam regulasi transkripsi protein, namun jika berada dalam jumlah yang tinggi, akan menyebabkan terjadi perubahan pada fungsi utamanya dan mengkatalis berbagai perubahan fisiologis (Zangger et al., 1999). Dijelaskan oleh Hal \& Lorraine (2003) bahwa yang termasuk dalam kategori logam berat esensial adalah $\mathrm{Fe}$ yang merupakan komponen dari protein hem dan beberapa jenis enzim. Sementara $\mathrm{Cu}$ merupakan komponen integral dari protein transfer elektron pada fotosisntesi (misalnya plastosianin) dan respirasi (oksidasi sitokrom c) serta terlibat dalam proses signifikasi sedangkan Mn merupakan logam berat jenis non redoks tetapi juga berperan dalam fotosintesis (misalnya perubahan $\mathrm{O}_{2}$ ). Selanjutnya, $\mathrm{Zn}$ adalah logam non- redoks tetapi merupakan komponen integral atau katalis yang beperan pada banyak protein dan enzim. Berdasarkan sifat kimia dan fisikanya, tingkat toksisitas atau daya racun logam berat terhadap hewan air dapat diurutkan (dari tinggi ke rendah) sebagai berikut merkuri (Hg), kadmium (Cd), seng $(\mathrm{Zn})$, timah hitam $(\mathrm{Pb})$, krom $(\mathrm{Cr})$, nikel (Ni), dan kobalt (Co) (El-Said et al., 2010).

Dailianis \& Kaloyianni (2004) menjelaskan bahwa logam berat di dikategorikan sebagai substansi yang paling toksik di antara polutan-polutan lainnya yang mengontaminasi lingkungan perairan laut. Galami et.al (2010) menjelaskan bahwa keberadaan logam berat di dalam lingkungan dapat menyebabkan terjadinya pencemaran karena sifatnya yang tidak dapat di degradasi melalui proses biologis maupun kimia. Pada lingkungan perairan, logam berat umumnya akan terakumulasi di dalam sedimen dan biota perairan (Gbrauko \& Friday, 2007; Sobolev \& Begonia, 2008). Amin et al. (2005) menjelaskan bahwa 90\% logam berat yang mengontaminasi lingkungan perairan akan terendapat di dalam sedimen. (Gbrauko \& Friday, 2007) menambahkan bahwa konsentrasi 
logam berat di perairan bervariasi bergantung pada fluktuasi musim. Lebih lanjut Gbrauko \& Friday (2007) menyatakan bahwa jumlah logam berat yang terakumulasi dalam tubuh biota perairan bergantung pada efek kimia logam berat tersebut dan cenderung berikatan dengan protein dan lipid pada jaringan biologis. Jenis protein yang menjadi target utama bagi perlekatan dengan logam berat adalah proteinprotein yang memiliki kandungan logam pada struktur proteinnya (Gong et al., 2000). Schutzendubel \& Polle (2002), membedakan mekanisme toksisitas logam berat menjadi 3 yaitu: 1) produksi reactive oksigen spesies dan reaksi fenton, 2) menghambat gugus fungsional biomolekul dan 3) merelokasi ion-ion logam esensial dari biomolekul.

Kontaminasi logam berat
terhadap ekosistem perairan telah
menjadi masalah dalam kesehatan
lingkungan selama beberapa decade.

Kontaminasi logam berat pada ekosistem perairan secara intensiv berhubungan dengan pelepasan logam berat oleh limbah domestik, industri dan aktivitas manusia lainnya. Kontaminasi logam berat dapat menyebabkan efek mematikan terhadap organisme laut dan menyebabkan ketidakseimbangan ekologis dan keanekaragaman organisme laut (Farombi et al., 2007, dalam Vinodhini \& Narayanan, 2008). Shah (2005) juga menjelaskan bahwa logam berat telah diketahui sejak lama sebagai polutan yang berbahaya bagi lingkungan akuatik.

Terkait dengan efek logam berat, Valko et al. (2005) menyatakan bahwa studi-studi yang dilakukan selama dua dekade menunjukkan bahwa jenis-jenis logam seperti besi (Fe), Cuprum (Cu), Kadmium (Cd), Merkuri $(\mathrm{Hg})$, Nikel (Ni) memiliki kemampuan untuk merusak DNA, peroksidasi lipid, inaktivasi protein dan efek lainnya. Efek lain yang ditimbulkan oleh logam berat ketika terkontaminasi dalam jumlah yang relatif tinggi adalah terjadinya produksi reaktif oksigen spesies (ROS) yang memicu tekanan oksidatif akibat ketidakseimbangan dengan sistem antioksidan sel (Choudhary et al., 2006; Hall, 2002; Flora et al., 2008). Dijelaskan pula oleh Dauwe et al. (2004) bahwa logam berat dapat menyebabkan efek negatif pada hampir semua tingkat organisasi kehidupan yaitu dari tingkatan biokimia, fisiologis hingga pada tingkatan populasi. 
Schurtzendubel \& Polle (2002) menjelaskan bahwa untuk memahami mekanisme toksisitas logam berat pada sel hidup, maka harus dipertimbangkan karakteristik kimia logam berat tersebut. Dijelaskan lebih lanjut bahwa kebanyakan logam berat merupakan logam berat transisi dengan keberadaan $\delta$-orbital sebagai kation pada kondisi fisiologis. Menurut Mandal (2006), perubahan pada tingkatan organisasi kehidupan akibat paparan logam berat, dibagi menjadi dua bagian yaitu perubahan yang tampak (visible injury), ketidaknormalan yang terjadi pada penampakan sehingga dapat dilihat dengan mata, sedangkan perubahan yang terjadi pada tingkatan kehidupan biokimia maupun fisiologis merupakan hidden injury atau perubahan yang tidak tampak. Dijelaskan lebih lanjut oleh Schurtzendubel \& Polle (2002) bahwa mekanisme toksisitas logam berat yang paling penting adalah kemampunya untuk berikatan dengan oksigen, nitrogen dan atom sulfur. Dijelaskan lebih lanjut bahwa kemampuan logam untuk berikatan dengan atom-atom tersebut berhubungan erat dengan entalpi bebas dari bentuk metal dan ligan. Sifat elektrokimia logam berat pada lingkungan perairan diperlihatkan pada Tabel 1, sebagai berikut.

Tabel 1. Sifat Elektrokimia (mV) Logam Berat pada Lingkungan Perairan $\left(\mathrm{pH} 7,2^{\circ} \mathrm{C}\right)$

\begin{tabular}{cc}
\hline $\begin{array}{c}\text { Kation } \\
\text { Logam }\end{array}$ & $\begin{array}{c}\text { Potensial } \\
\text { Redoks }(\mathbf{m V})\end{array}$ \\
\hline $\mathrm{Zn}^{2+}$ & $-1,18$ \\
$\mathrm{Cd}^{2+}$ & $-0,82$ \\
$\mathrm{Ni}^{2+}$ & $-0,65$ \\
$\mathrm{~Pb}^{2+}$ & $-0,55$ \\
$\mathrm{Cu}^{2+}$ & $-0,26$ \\
$\mathrm{Fe}^{2+}$ & $+0,35$ \\
$\mathrm{Hg}^{2+}$ & $+0,43$ \\
$\mathrm{Ag}^{2+}$ & $+1,57$ \\
\hline
\end{tabular}

Mekanisme Absorpsi dan Toksisitas Logam Berat Kadmium di Perairan

Cd merupakan logam berat non esensial (Olivi et al., 2001; Martin \& Prognonec, 2009), menurut Pal (2006), bahwa pada konsentrasi yang tinggi, kadmium merupakan logam berat yang bersifat karsinogen, mutagenik dan teratogenik pada beberapa jenis hewan. Berdasarkan sifatnya yang merupakan bahan karsinogenik, Internation Agency for Research on Cancer of USA menempatkan kadmium pada peringkat pertama bahan karsinogen yang sangat berbahaya (Flora et al., 2008). Dijelaskan pula oleh Jonak et al. (2004) bahwa kadmium tidak diketahui memiliki fungsi biologis di dalam sel tetapi memiliki sifat reaktif yang sangat 
inggi dan dapat menginaktifkan berbagai macam aktivitas enzim yang diperlukan oleh sel. Setelah diabsorbsi, logam berat kadmium akan terakumulasi di dalam organ target yang utamanya adalah ginjal kemudian menimbulkan toksisitas (Rico et al., 2002). Di dalam ginjal, akumulasi kadmium terjadi umumnya di dalam tubulus proximal serta segmen-segmen nefron lainnya yang hanya terjadi pada akhir tahap intoksifikasi (Yokouchi et al., 2007). Penelitian yang dilakukan oleh Ohta et al (2000) menemukan bahwa pemberian logam berat kadmium terhadap tikus putih jantan (Male Wistar Rats) dapat menyebabkan osteoporosis serta umumnya terdeposit di dalam organ liver dan ginjal.

Pada tingkatan biomolekuler, kadmium diabsorbsi oleh organisme dan terakumulasi di dalam sitosol melalui pembentukan kompleks metal-ligan (Dailanis \& Kaloyianni, 2004). Kadmium dapat menginduksi kerusakan pada fungsi membran dengan merusak komposisi lipid pada membran sel (Smiri et al., 2010; Dailanis \& Kaloyianni, 2004). Penelitian yang dilakukan oleh El-Maraghy et al. (2001) dan Wlostowski et al. (2003) yang dirujuk dalam Faix et al. (2005) menyimpulkan bahwa paparan logam berat jenis kadmium menyebabkan perubahan histopatologi dan peroksidasi lipid pada organ liver dan ginjal hewan rodent. Efek lainnya yang ditimbulkan oleh logam berat kadmium adalah terjadi pengurangan berat badan roden (Almeide et al., 2009). Almeide et al. (2010) juga menemukan bahwa paparan logam berat kadmium dapat menyebabkan retardasi (perlambatan) pertumbuhan serta menghambat pengambilan ion kalsium pada insang ikan.

Dijelaskan lebih lanjut oleh Smiri et al. (2010) bahwa kadmium menginduksi toksisitas atau menimbulkan efek toksik melalui kemampuannya dalam menimbulkan stres oksidatif yang dimediasi oleh $\mathrm{H}_{2} \mathrm{O}_{2}$ yang akan memicu peningkatan reduksi aktivitas enzim-enzim antioksidan seperti catalase dan peroxidase bersamaan dengan meningkatnya peroksidasi lipid, produksi superoksida radikal (Smiri et al., 2010; Ali et al., 2009). Gzyl et al. (2009) menjelaskan bahwa kadmium tidak dapat berpartisipasi pada reaksi redoks tetapi memiliki kemampuan untuk memproduksi radikal bebas. Penelitian Almeida et al. (2009) 
menemukan bahwa logam berat kadmium meningkatkan peroksidasi lipid pada liver Nile talipia. Melalui perlekatannya dengan residu cystein atau memicu pembentukan ROS, logam berat kadmium diketahui menunjukkan efek terhadap proses genomic dan postgenomic pada liver, ginjal paruparu dan otak. Kerusakan yang sama juga tampak berhubungan dengan disfungsi neuron pada hipotalamus, pituitary dan testiskular (Giusi et al., 2005). Selain itu, kadmium juga menginduksi gejala kerusakan peroksisome pada daun (tumbuhan) dengan menginduksi enzim siklus glikosilat, malat sintetase dan isositrat liase yang merupakan peroksisom peptidase (Smiri et al., 2010). Peran kadmium dalam menginduksi signal tranduksi intraseluler dijelaskan oleh Dailanis \& Kaloyianni (2004), bahwa kadmium mengaktifkan signal transduksi cascade seperti PKC, tirosin kinase dan casein kinase II. Rocheri et al. (2004) juga menjelaskan bahwa mitokondria merupakan salah satu target seluler dari kadmium melalui efeknya secara langsung terhadap peningkatan permeabilitas iner membran.
HASIL DAN PEMBAHASAN

Biomonitoring Logam Berat Sebagai

Alat Asesmen Kualitas Perairan

\section{Pengertian Biomonitoring}

Berbagai ahli lingkungan telah memberikan pendapatnya tentang apa itu biomonitoring. Berikut ini diungkapkan pengertian biomonitoring sebagaimana yang terlihat pada beberapa kutipan langsung, sebagai berikut.

1. Webster's dictionary defines monitoring as (1) to check and sometimes to adjust for quality or fidelity, (2) to watch, observe or check, especially for a special purpose, (3) to keep track of, regulate, or control (as a process for the operation of a machine) (de Zwart, 1995).

2. Biomonitoring is a collective term for all the techniques that use living organisms to provide information about both abiotic (non-living) and biotic (living) components of an environment (Day, 2000).

3. Biomonitoring is the process of evaluating aquatic conditions; it answers two questions: (1) Does water quality vary over time and space; and (2) are management 
Biomonitoring: Sebagai Alat Asesmen Kualitas ...

efforts resulting in progress toward sustainability (i.e., are aquatic ecosystems minimally impacted) (Jones and Craig, 2004)

4. Biomonitoring is the use of living material to confirm or validate that previously established quality control conditions important to living systems are being me (Cairns, 2005).

5. Biological monitoring has many advantages in comparison with the traditional analysis of abiotic matrices (water, sediments); it has proven to be a precious means to evaluate environmental quality and its administration is also provided for by the law regulating waters protection (Conti, 2002; Conti and Cecchetti, 2001 dalam Conti et al., 2005).

6. Biomonitoring is the use of biological variables to survey the environment. The primary task in biomonitoring is the search for the ideal indicator (or bioindicator) whose presence, abundance, and/or behavior reflects a stressor's effect on biota

7. Biomonitoring, defined as measuring the concentration of chemicals or their metabolites in blood, urine, breast milk, hair and other biological samples (Hays, et al., 2007).

8. Biomonitoring, the measurement of the concentrations of chemical substances in human body fluids and tissues (Boogaard and Money., 2008).

9. Biomonitoring merupakan teknik evaluasi lingkungan berdasarkan analisis pada jaringan dan molekul organisme yang terpapar logam berat (Zhou et al., 2008).

10. Biological monitoring (biomonitoring) has the ability to integrate total chemical exposure to assess human dosimetry. This includes exposure from multiple sources (i.e., air, soil, water, and food residues) and multiple routes of intake (i.e., inhalation, oral, and dermal). A benefit of biomonitoring is the ability to associate the internal dose of a given chemical or metabolite with a measurable effect (either tissue specific or whole body), whichcan then be used for risk assessment purposes (Barry et al., 2009).

11. Ayeni et al. (2010) mendefisikan biomonitoring sebagai spesiesspesies yang dapat memberikan 
informasi terkait dengan status pencemaran lingkungan oleh polutan tertentu.

Berdasarkan pengertian dari kutipan-kutipan langsung tersebut, dapat dikatakan bahwa definisi biomonitoring yang diungkapkan hanya pada tataran substansial maupun operasional. Dengan memperhatikan hal tersebut, dapat dijelaskan bahwa biomonitoring adalah suatu rangkaian proses evaluasi kualitas perairan dengan cara mengukur keberadan polutan tertentu pada matriks lingkungan maupun di dalam kompartemen tubuh organisme tertentu yang dapat memberikan informasi tentang status/kualitas suatu lingkungan. Pengukuran matriks lingkungan dapat dilakukan dengan memperhatikan keanekaragaman, kepadatan, pola distribusi suatu organism dan mengkorelasikan dengan factor-faktor lingkungan yang mempengaruhi kestabilan lingkungan tersebut, seperti substrat, salinitas, $\mathrm{pH}$, okseigen terlarut dll. Selain itu, informasi dari hasil analisis kimia pada kompartemen tubuh suatu organism dapat memberikan data tentang tingkat akumukasi suatu senyawa yang keberadaannya mengganggu system tubuh suatu organisme.

Terkait dengan biomonitoring logam berat, tidak hanya terbatas pada tingkat evaluasi lingkungan tetapi juga terhadap efek yang timbul pada manusia. Hal ini sesuai dengan pendapat Kamrin (2004) dan Angerer et al. (2006) yang mendefinisikan biomotoring sebagai teknik evaluasi lingkungan terhadap paparan bahan kimia berdasarkan sampling dan analisis jaringan, cairan dan jaringan individu. Berdasarkan pengertian-pengertian yang telah diungkapan, maka disimpulkan bahwa biomonitoring adalah penggunaan suatu spesies tertentu yang dapat memberikan informasi terkait dengan status pencemaran lingkungan oleh logam berat tertentu berdasarkan analisis matriks lingkungan, analisis jaringan dan molekul organisme yang terpapar logam berat.

Mengapa Harus Menggunakan Biomonitoring

Selama beberapa dekade terakhir, biomonitoring telah banyak digunakan sebagai pendekatan untuk mengestimasi stasus pencemaran logam berat di berbagai lingkungan, seperti udara (Chettri et al., 2000), tanah (Friedlova, 2010), sungai (Wepener et 
Biomonitoring: Sebagai Alat Asesmen Kualitas ...

al., 2005) dan laut (Kobayashi and Okamura, 2004; Flammang et al., 1997; Phillips, 1990).

Menurut Warlina (2004), secara umum terdapat 2 (dua) usaha untuk mengendalikan pencemaran, yaitu penanggulangan secara non-teknis dan secara teknis. Penanggulangan secara non-teknis yaitu suatu usaha untuk mengurangi pencemaran lingkungan dengan cara menciptakan peraturan perundangan yang dapat merencanakan, mengatur dan mengawasi segala macam bentuk kegiatan industri dan teknologi sehingga tidak terjadi pencemaran. Sedangkan penanggulangan secara teknis bersumber pada perlakuan industri terhadap perlakuan buangannya, misalnya dengan mengubah proses, mengelola limbah atau menambah alat bantu yang dapat mengurangi dan menghilangkan pencemaran.

Secara teknis, upaya pengendalian pencemaran logam berat dapat dilakukan dengan 2 cara, yakni pengendalian dengan menggunakan proses kimia dan penanganan dengan menggunakan mikroorganisme atau mikroba. Dengan proses kimia dilakukan dengan penambahan senyawa kimia tertentu untuk proses pemisahan ion logam berat atau dengan resin penukar ion (exchange resins), serta beberapa metode lainnya seperti penyerapan dengan menggunakan karbon aktif, electrodialysis dan reverse osmosis. Penanganan logam berat dengan mikroorganisme atau mikroba menjadi alternatif yang dapat dilakukan untuk mengurangi tingkat keracunan elemen logam berat di lingkungan perairan.

Pengendalian pencemaran logam berat secara teknis seperti yang diungkapkan oleh Warlina (2004) belum secara menyeluruh memberikan informasi yang komprehensif terkait dengan usaha pengendalian pencemaran logam berat di perairan. Untuk itu, maka diperlukan suatu proses evaluasi kualitas perairan dengan cara mengukur keberadan polutan tertentu pada matriks lingkungan maupun pada organisme tertentu di perairan, yakni dengan melakukan biomonitoring akumulasi.

Zhou et al. (2008) juga menjelaskan bahwa analisis matriks lingkungan seperti air dan sedimen merupakan pendekatan langsung yang dilakukan untuk mengetahui tingkat pencemaran lingkungan, tetapi tidak dapat memberikan informasi yang komprehensif terkait dengan 
kemungkinan efek toksik logam berat bagi perkembangan organisme sehingga dapat digunakan sebagai indikator pencemaran logam berat. Kamrin (2004) juga menjelaskan bahwa biomonitoring digunakan untuk mengukur jumlah bahan kimia, termasuk logam berat, yang terdapat di lingkungan. Respons yang timbul pada organisasi seluler memang diperlukan untuk memastikan keberadaan logam berat di lingkungan, tetapi seberapa besar respons seluler dapat berpengaruh pada tingkatan organisasi yang lebih tinggi yaitu individu, populasi dan komunitas masih harus dilakukan kajian untuk memperoleh hasil yang lebih mendetail (Schoettger, 1996). Dengan demikian, maka metode biomonitoring diharapkan dapat memberikan informasi yang komperehensif terkait dengan kondisi lingkungan.

Day (2000) menjelaskan bahwa hal yang paling fundamental dari penggunaan metode biomoniotoring adalah bahwa organisme hidup dapat merefleksikan kondisi lingkungan tempat hidupnya sehingga jika terjadi perubahan pada beberapa aspek lingkungan maka akan berimplikasi pada organisme tersebut. Selain itu, Barry et al. (2009) juga menjelaskan bahwa biomonitoring memiliki keunggulan yang terintegrasi sehingga dapat digunakan dalam menentukan jumlah logam berat yang terpapar pada manusia. Dengan demikian, data hasil biomonitoring dapat digunakan sebagai dasar pengambilan keputusan dan manajemen lingkungan serta penilaian tingkat resiko (risk assessment) lingkungan (Agrerer et al., 2006).

\section{Ruang Lingkup dan Teknik-Teknik \\ Biomonitoring}

Biomonitoring logam berat khususnya pada lingkungan akuatik, metode atau teknik yang berbeda dapat digunakan berdasarkan pada tujuan dan keinginan yang berebeda pula. Misalnya, analisis kimia dalam organisme yang terkena polusi, penentuan kadar logam berat dalam organisme yang spesifik, pengukuran aktivitas enzim dalam bioindikator yang terkena polusi, pengamatan histopatologi dan analisa kandungan biomarker seperti misalnya pigmen fotosintetik dalam ganggang. Semua perubahan dalam fungsi fisiologi, kelimpahan spesies, populasi, komunitas organisme akuatik juga dapat berkorespondensi dengan kondisi ekosistem perairan. 
Biomonitoring: Sebagai Alat Asesmen Kualitas ...

Berdasarkan pengertian biomonitoring yang telah dijelakan sebelumnya, maka dapat dijelaskan ruang lingkup biomonitoring. Ruang lingkup yang dimaksud meliputi variable-variabel yang menjadi objek kajian dalam biomonitoring (de Zwart, 1995). Variabel-variabel yang menjadi objek kajian dalam biomonitoring, menurut Zhou et al. (2008) berupa teknik/metode dalam program biomonitoring, meliputi bioakumulasi, perubahan biokimia, pengamatan morfologi dan perilaku, pendekatan level-populasi dan komunitas. Masingmasing teknik menunjukkan kelebihannya masing-masing dan dapat diaplikasikan dalam berbagai bidang. Teknik/metode dalam program biomonitoring atau yang dikenal dengan variable-variabel biomonitoring, yaitu biomonitoring akumulasi (bioakumulasi), biomonitoring toksisitas, dan biomonitoring ekosistem. Berikut ini akan dijelaskan biomonitoring akumulasi sebagai alat asesmen kualitas perairan akibat logam berat kadmium pada invertebrata perairan.

Bioakumulasi merupakan proses penting dimana bahan kimia dapat mempengaruhi organisme hidup. Zhuo,
Q et al. (2008) menjelaskan bahwa bioakumulasi berhubungan dengan peningkatan konsentrasi bahan kimia dalam suatu materi biologis organisme selama kurun waktu tertentu dan dibandingkan dengan konsentrasi bahan kimia tersebut di dalam lingkungan. Bioakumulasi terjadi ketika sebuah organisme menyerap sebuah senyawa beracun pada tingkat yang lebih tinggi daripada pelepasan senyawa tersebut.

Monitoring bioakumulasi merupakan pengukuran konsentrasi logam berat yang terdapat dalam materi biologis. Weigel (2004) dalam Ayeni et al. (2010) mendefisikan bioakumulasi sebagai akumulasi jenis-jenis polutan, termasuk logam berat, dalam organisme yang lebih tinggi dibanding dengan yang terdapat pada lingkungan. Zhou (2008) menjelaskan bahwa bioakumulasi merupakan proses penting yang menyebabkan efek pada organisme. Gad et al. (2010) menyebutnya sebagai bioabsorbsi yang didefenisikan sebagai metabolisme terhadap bahan-bahan pencemar. Zauke (2008) menjelaskan bahwa evaluasi logam berat yang dapat masuk ke dalam tingkatan tropik rantai makanan dapat dilakukan dengan menentukan jumlah logam berat pada suatu organisme. Pola 
akumulasi dan konsentrasi logam berat yang terdapat dalam organisme laut dapat dideskripsi dan diprediksi melalui model toksikokinetik.

Peningkatan konsentrasi logam berat di dalam organisme kemudian dibandingkan dengan konsentrasi logam berat yang terdapat pada lingkungan. Bioakumulasi terjadi ketika organsime mengabsorbsi logam berat dalam jumlah yang melebihi ambang batas dan meliputi beberapa proses yaitu pengambilan (uptake), penyimpanan (storage) dan pengeluaran (elimination). Ditegaskan oleh Zhou, Q et al. (2008) bahwa stidaknya terdapat proses termasuk uptake, penyimpanan dan penghilangan yang terlibat selama bioakumulasi. Bioakumulasi terjadi dari sebuah ekuilibrium dinamis antara pemaparan dari lingkungan luar dan uptake, ekskresi, penyimpanan dan degradasi di dalam tubuh organisme.

Memahami proses dinamika bioakumulasi adalah pertimbangan yang kritis dalam regulasi kimia seperti misalnya logam-logam akuatik. Gbaruko dan Friday (2007) menjelaskan bahwa akumulasi logam sangat bergantung pada efek kimia logam berat tersebut untuk berikatan dengan komponen-komponen tertentu pada sel serta jaringan tubuh organisme yang terpapar logam berat. Penjelasan lebih spesifik diberikan oleh Maanan (2007) bahwa faktor-faktor yang mempengaruhi akumulasi logam berat pada suatu organisme tergantung pada keberadaan logam berat, musim, hidrodinamik lingkungan, ukuran, jenis kelamin, perubahan-perubahan pada komposisi jaringan dan siklus reproduksi.

Shah (2005) menunjukkan bahwa logam berat jenis $\mathrm{Pb}$ lebih tinggi pada organ liver dibanding dengan insang, otot, testis dan ovarium ikan Tinca tinca L. Hasil penelitian Shah (2005) juga menunjukkan bahwa akumulasi logam berat $\mathrm{Pb}$ lebih tinggi dibanding dengan $\mathrm{Hg}$ dan $\mathrm{Cd}$. Penelitian yang dilakukan oleh Temara et al. (1998) menemukan bahwa Asteria rubens membutuhkan waktu yang relatif panjang untuk mengakumulasi logam berat $\mathrm{Pb}$ pada tulang dibanding dengan jenis logam berat $\mathrm{Cd}$ dan $\mathrm{Zn}$. Penelitian yang dilakukan oleh Vinodhini dan Narayanan (2008) juga menemukan adanya perbedaan akumulasi logam berat $\mathrm{Pb}, \mathrm{Cd}, \mathrm{Ni}$ dan $\mathrm{Cr}$ pada organ tubuh Cyprinus carpio, dimana akumulasinya lebih tinggi pada organ hati. Adanya perbedaan akumulasi 
Biomonitoring: Sebagai Alat Asesmen Kualitas ...

logam berat ini disebabkan oleh kebisaan makan dan perilaku mencari makan (Shah, 2005). Temara et al. (1998) juga menjelaskan bahwa akumulasi $\mathrm{Pb}$ dan $\mathrm{Cd}$ pada kompartemen tubuh Asterias rubens berhubungan dengan kadar logam berat tersebut pada air laut. Penelitian lainnya yang menggunakan echinoidea jenis Paracentrotus lividus oleh Soualili et al. (2007) menemukan bahwa gonad betina dapat mengakumulasi logam berat dengan konsentrasi yang tinggi dan berhubungan dengan konsentrasi logam berat dalam sedimen.

\section{KESIMPULAN}

Berdasarkan uraian yang telah diungkapkan, maka dapat diambil beberapa kesimpulan sebagai berikut.

(1) Kadmium merupakan elemen ke-48 dan merupakan anggota dari kelompok 12 pada sistem tabel periodik dan merupakan jenis logam berat yang memiliki toksisitas yang tinggi, penyebaran yang luas serta memiliki waktu paruh (biological life) yang panjang dalam tubuh organisme hidup.

(2) Kadmium pada lingkungan perairan, secara cepat terdeposit pada organisme perairan dalam bentuk ion-ion bebas dalam bentuk $\mathrm{Cd}^{2+}$. (3) Sumber utama kontaminasi kadmium pada lingkungan yaitu melalui lapisan bumi dan aktivitas manusia (antropogenic). Secara alami, kadmium merupakan unsur utama fosfat bebatuan dan terdeposit dalam lapisan bumi. Sumber kadmium dari aktivitas manusia yakni aktifitas industri panas bumi, industri bahan bangunan, areal pertambangan, industri logam. Selain itu, kadmium sering digunakan sebagai pewarna cat dan plastik, sebagai katoda nikel, baterai dan alat elektronik. (4) Kontaminasi logam berat $\mathrm{Cd}$ menyebabkan efek mematikan terhadap organisme laut dan menyebabkan ketidakseimbangan ekologis dan keanekaragaman organisme laut. (5) Mekanisme absorpsi dan toksisitas logam berat kadmium pada organisme perairan terjadi pada tingkatan biomolekuler. Kadmium yang masuk ke dalam sel menimbulkan efek toksik dan menimbulkan stres oksidatif sehingga merusak komposisi lipid pada membran, dan menyebabkan perubahan histopatologi dan peroksidasi lipid pada organ liver dan ginjal, menyebabkan retardasi (perlambatan) pertumbuhan serta menghambat pengambilan ion kalsium. (6) Biomonitoring merupakan suatu sistem evaluasi lingkungan yang dilakukan secara komprehensif untuk 
pengendalian pencemaran logam berat.

Monitoring bioakumulasi

merupakan proses penting yang menyebabkan efek pada organism. Monitoring bioakumulasi dilakukan dengan mengukur konsentrasi logam berat yang terdapat dalam materi biologis dan lingkungan.

\section{SARAN}

Berdasarkan paparan konseptual yang telah diungkapkan, maka disarankan beberapa hal, sebagai berikut. (1) Kepada pemerintah dan instansi terkait untuk lebih tegas dalam memberikan sanksi bagi pelaku industri dalam penanganan limbah buangan akibat aktifitas industri. (2) Kepada pelaku industri, untuk sedapat mungkin mengelolah limbah buangan sebelum dibuang ke lingkungan perairan. (3) Kepada peneliti, untuk mengkaji tentang efek logam berat yang ada pada organisme perairan dan dampaknya bagi kesehatan manusia serta mereancang suatu sistem biomonitoring terhadap lingkungan dengan menggunakan biota perairan sabagai bioindikator pencemaran.

\section{DAFTAR PUSTAKA}

Agnello, M., Filosto, S, Scudiero, R., Rinaldi, A.M., and Roccheri, M.C. 2007. Cadmium Induces an Apoptotic Response in Sea Urchin Embryos. Cell Stress \& Chaperones. Vol 12 (1): 44-50, 2007.

Angerer, J., Bird, M.G., Burke, T.A., Doerrer, N.G., Needham, L., Robinson, S.H., Sheldon, L., and Zenick, H. 2006. Strategic Biomonitoring Initiatives: Moving the Science Forward. Toxicological Science, Vol 93(1): 3-10, 2006.

Ali, C., Réda, D.M., Rachid, R., and Houria, B. 2009. Cadmium Induced Changes in Metabolic Function of Mitochondrial Isolated from Potato Tissue (Solanum tuberosum L.). American Journal of Biochemistry and Biotechnology, Vol 5 (1): 35-39, 2009.

Almeida, J.A., Barreto, R.E., Novelli, L.B., Castro, F.J., and Moron, S.E. 2009. Oxidative Stress Biomarkers and Aggressive Behavior in Fish Exposed to Aquatic Cadmium Contamination. Neotropical Ichtyology, Vol 7(1): 103-108, 2009.

Amin, B., Ismail, A., Arshad, A., Yap, C.K., and Kamarudin, M.S. 2009. Anthropogenic Impacts on Heavy Metal Concentrations in the Coastal Sediments of Dumai, Indonesia. Environ Monit Assess, Vol 148:291-305, 2009.

Amisah, S., Boateng, D., Obirikorang, K.A., and Quagrainie, K.K. 
2009. Effects of Clam Size on Heavy Metal Accumulation in Whole Soft Tissues of Galatea paradoxa (Born, 1778) from the Volta Estuary, Ghana. Full Length Research. International Journal of Fisheries and Aquaculture Vol. 1 (2): 14-21, July 2009.

Apperonth, K.J. 2010. Defenition of Heavy Metal and Their Role in Biological Systems. Chapter 2. Soil Heavy Metals, Soil Biology. Vol. 19.

Ayeni, O.O., Ndakidemi, P.A., Snyman R.G., and Odendaal J.P. 2010. Chemical, Biological and Physiological Indicators of Metal Pollution in wetlands. Review. Scientific Research and Essays. Vol 5 (15): 1938-1949, August, 2010.

Barry, R.C., Lin, Y., Wang, J., Liu, G., and Timchalk, A. 2009. Nanotechnogy-Based Electrochemical Sensors for Biomonitoring Chemical Exposures. Review. Journal of Exposure Science and Environmental Epidemiology, Vol 19: 1-18, 2009.

Cairns, J.Jr. 2005. Biomonitoring: The Crucial Link Between Natural Systems and Society. Mankind Quarterly, Volume XLV (3): 289-308, 2005.

Chakrabortty, S and Paratkar, G.T. 2006. Biomonitoring of Trace Element Air Pollution Using Mosses. Aerosol and Air Quality Research, Vol 6 (3): 247-258, 2006
Carpene, E., Andreani, G., and Isani, G. 2007. Metallothionein Functions and Structural Characteristcs. Journal of Trace Elements in Medicine and Biology. (online) www.elsevier.de/jtemb. Diakses 12 September 2010.

Choudhury, S \& Panda, S.K. 2004. Induction of Oxidative Stres and Ultrastructural Chages in moss Taxithelium nepalense (Schwaegr) Broth, Unde Lead and Arsenic Phytotoxicity. Current Science, Vol. 87 (3), 10 August 2004.

Choudhury, M., Jetley, U.K., Khan, M.A., Zutshi, S., and Fatma, T. 2006. Effect of Heavy Metal Stres on Proline, Malondialdehyde, and Superoxide Dismutase Acivity in the Cyanobacterium Spirulina platensis-S5. www.elsevier.com. Diakses tanggal 17 Oktober 2010.

Conti, M.E., Lacobucci, M., and Cecchelti, G. 2005. A Statistical Approach Applied to Trace Metal Data from Biomonitoring Studies. Int. J. Environment and Pollution, Vol 23, No. 1, 2005.

Dahuri, R., Jacub, R., Ginting, S.P., dan Sitepu, M.J. 2004. Pengelolaan Sumberdaya Wilayah Pesisir dan Lautan Secara Terpadu. Cetakan Ketiga. Jakarta: Pradnya Paramita

Dailianis, S \& Kaloyianni, M. 2004. Cadmium Induces Both Pyruvate Kinase and $\mathrm{Na}^{+} / \mathrm{H}^{+}$ Exchanger Activity Through Protein Kinase C Mediated Signal Transduction, in Isolated 
Digestive Gland Cellss of Mytilus galloprovincialis (L.). The Journal of Experimental Biology, Vol 207: 1665-1674.

Dauwe, T., Janssens, E., Kempenaers, B., and Eens, M. 2004. The Effect of Heavy Metal Exposure on Egg Size, Eggshell Thick.ess and the Number of Spermatozoa in Blue Tit Parus Caeruleus Eggs. Environmental Pollution, Vol 129: 125-12, 2004. www.elsevier.com/locate/envpol

Day, J. 2000. Biomonitoring: Appropriate Technology for the $21^{\text {st }}$

Century.WARFSA/WaterNet

Symposium: Sustainable Use of Water Resources, Maputo, 1-2 November 2000.

de Michele, R., Vurro, E., Rigo, C., Costa, A., Elviri, L., Di Valentine., Careri, M., Zottini, M., di Topi, S., and Schiavo, F.L. 2009. Nitric Oxide is Involved in Cadmium-Induced Programme Cell Death in Arabidopsis Suspension Cultures. Plant Physiology, Vol 150: 217-228, May 2009.

de Zwart. 1995. Monitoring Water Quality in the Future. Volume 3: Biomonitoring. Bilthoven, The Netherlands April, 1995.

Duruibe, J.O., Ogwuegbu, M.O.C., and Egwurugwu, J.N. 2007. Heavy Metal Pollution and Human Biotoxic Effects. Full Length Research Paper. International Journal of Physical Sciences, Vol 2 (5): 112-118, May 2007.
El-said, A.G., Badawy, N.A., and Garamon, S.E. 2010. Adsorption of Cadmium (II) and Mercury (II) Otto Natural Adsorbent Risk Husk Ash (AHA) from Aqueous Sollutions: Study in Singlet and Binary System. Journal of American Science, Vol 6 (12), 2010.

Faix, S., Faixova, Z, Boldizarova, K., and Javorsky, P. 2005. The effect of long-term high Heavy metal intake on lipid peroxidation of gastrointestinal tissue in sheep. Vet. Med-Czech, Vol 50 (9): 401-405, 2005.

Flora, S.J.S., Mittal, M., and Mehta, A. 2008. Heavy Metal Induced Oxidative Stres \& its Possible Reversal by Chelation Therapy. Indian J. Med. Vol 128: 501523, Oktober 2008.

Flora, S.J.S. 2009. Metal Poisoning: Treatment and Management. Review Article. Al Ameen $J$. Med. Sci, Vol 2 (2): 4-26, 2009.

Friedlova, M. 2010. The Influence of Heavy Metal on Soil Bioloigical and Chemical Properties. Soil \& Water, Vol 5 (1): 21-27, 2005.

Gad, A.S., Attia, M., and Ahmed, H.A. 2010. Heavy Metal BioRemediation by Immbolized Saccharomyces cereviseae and Opuntia ficus indica Waste. Journal of American Science, Vol 6 (8), 2009.

Galabi, M., Jalai, A., and Ramroodi, M. 2010. Effects of Treated Municipal Wastewater on Soil Chemical Properties and Heavy Metal Uptake by Sorgum 
(Sorgum bicolor L). Journal of Agricultural Science. Vol 2. No. 3, September 2010.

Gbaruko, B.C., and Friday, O.U. 2007. Bioaccumulation of Heavy Metals in Some Fauna and Flora. Email: bgbaruko@yahoo.com. Diakses 03 September 2010.

Giusi, G., Facciolo, R.M., Alò, R., Carelli, A., Madeo, M., Brandmayr, P., and Canonaco, M. 2005. Some Environmental Contaminants Influence Motor and Feeding Behaviors in the Ornate Wrasse (Thalassoma pavo) via Distinct Cerebral Histamine Receptor Subtypes. Environmental Health Perspectives, Volume 113. Number 11. November 2005

Gong, P., Ogra, Y., and Koizumi, S. 2000. Inhibitory Effects of Heavy Metals on Transcription Factor Sp1. Short Communication. Industrial Health, Vol 38: 224-227, 2008.

Hall, J.L. 2002.Cellular Mechanisms for Heavy Metal Detoxification and Tolerance. Review Article. Journal of Experimental Botany. Vol. 53, No. 366, pp. 1-11, January 2002.

Hall, J. L \& Lorraine, E.W. 2003. Transition Metal Transporters in Plants. Review Article. Journal of Experimental Botany, Vol 54 (393): 2601-2613, December 2003.

Hays, S.M,. Aylward, L.L., LaKind, J.L., Bartels, M.J., Barton, H.A., Boogaard, P.J., Brunk, C.,
DiZio, A., Dourson, M., Goldstein, D.A., Lipscomb, J., Kilpatrick E, Krewski E. Krishnan K, Nordberg M, Okino M, Tan Y. M, Viau, C., and Yager, J.W. 2008. Guidelines for the Derivation of Biomonitoring Equivalents: Report from the Biomonitoring Equivalents Expert Workshop. Regulatory Toxicology and Pharmacology. journal homepage:

www.elsevier.com/locate/yrtph

Hays, S.M., Aylward, L.L., LaKind, J.L., Bartels, M.J., Barton, H.A., Boogaard, P.J., Brunk, C., DiZio, A., Dourson, M., Goldstein, D.A., Lipscomb, J., Kilpatrick E, Krewski E. Krishnan K, Nordberg M, Okino M, Tan Y. M, Viau, C., and Yager, J.W. 2006. Biomonitoring Equivalents: A Screening Approach for Interpreting Biomonitoring Results from A Public Health Risk Perspective. www.elsevier.com. Diakses 8 September 2010

Jonak, C., Nakagami, H., and Hirt, H. 2004. Heavy Metal Stress. Activation Mitogen-Activated Protein Kinase Pathways by Copper and Cadmium. Plant Physiology, Vol. 136: 32763283, October, 2004.

Jones, C and Craig, B. 2004. The Ontario Benthos Biomonitoring Network. Leading Edge. The Working Biosphere, Vol 3 (5), Maret 2004.

Kamrin, M.A. 2004. Biomonitoring Basics. A Resport from 
Biomonitoringinfo.org.

Environmental Health Research Foundation.

Kaneta, M., Hikichi, H., Endo, E., and Sugiyama, N. 1986. Chemical form of Cadmium (and other Heavy Metal) in Rice and Wheat Plants. Environmental Health Properties, Vol. 65: 33-37, 1986.

Kortba, P., Doleckova, L., de Lorenzo, V., and Ruml, T. 1999. Enhanced Bioacumulation of Heavy Metal Ions by Bakterial Cells Due to Surface Display Of Short Metal Binding Peptides. Applied and Environmental Microbiology, Vol 65 (3): 10921098.

Krichah, R., Rhouma, K.B., Hallègue, D., Tébourbi, O., Joulin, V., Couton, D., and Sakly, M. 2003. Acute Cadmium Administration Induces Apoptosis in Rat Thymus and Testicle, but not Liver. Polish Journal of Environmental Studies. Vol 12 (5): 589-594, 2003.

Lindert, U., Cramer, M., Meuli, M., Georgiev, O., and Schaffner, W. $2009 . \quad$ Metal-Responsive Transcription Factor 1 (MTF-1) Activity is Regulated by a Nonconventional Nuclear Localization Signal and a MetalResponsive Transactivation Domain. Molecular and cellular Biology, Vol 29 (23): 62836293, Dec. 2009.

Maanan, M. 2007. Biomonitoring of Heavy Metals Using Mytilus galloprovincialis in Safi Coastal Waters, Morocco. (Online) www.interscience.willey.com.

Diakses tanggal 16 Oktober 2010.

Mandal, M. 2006. Physiological Changes in Certain Test Plants Under Automobile Exhaust Pollution. Journal of Environmental Biology. January 2006, 27(1) 43-47 (2006).

Maria, A., Filosto, S., Scudiero, R., Rinaldi, A.M., and Roccheri, M.C. 2006. Cadmium Accumulation Induces Apoptosis in $P$. Lividus Embryos. Caryologia, Vol 59 (4): 403-408, 2006.

Martin, L.M., Hesketh, J.E., Beattie, J.H., and Wallacet, H.M. 2001. Influence of Metallothionein-1 Localization on its Function. Biochem J, Vol 355: 463-479, 2001.

Martin, P \& Pognonec, P. 2010. ERK dan Cell Death: Cadmium Toxicity, Sustained ERK Activation and Cell Death. FEBS Journal, Vol 277: 39-46, 2010.

Miranda, M., Alonzo, M.L., Castilo, C., Hernandez, J., and Benedito J.L. 2005. Effects of Moderate Pollution on Toxic and Trace Metal Levels in Calves from a Polluted Area of Northern Spain. Enviromental International, Vol 31: 453-548, $2005 . \quad$ (online) www.elsevier.com. Diakses tanggal 12 September 2010.

Nordic. 2003. Cadmium Review. Prepared by COWI A/S on Behalf of the Nordic Council of Ministers. 
Biomonitoring: Sebagai Alat Asesmen Kualitas ...

Ohta, H., Yamauchi, Y., Nakakita, M., Tanaka, H., Asami, S,. Seki, Y and Yoshikawa, H. 2000. Relationship between Renal Dysfunction and Bone Metabolism Disorder in Male Rats after Long-Term Oral Quantitative Cadmium Administration. Industrial Health, Vol 38: 339-355, 2000.

Olive, L., Sisk, J., and Bressler, J. 2001. Involvement of DMT1 in uptake of Cd in MDCK Cells" Role of Protein Kinase C. Am. J. Physiol Cell, Vol 281: 793-800, 2001.

Ololade, I.A \& Olongundudu, A. 2007. Concentration and Bioavailability of Cadmium by Some Plants. African Journal of Biotechnology, Vol 6 (16): 1916-1921, 20 August 2007.

Pal, M., Horvarth, E., Janda, T., Paldi, E., and Szalai, G. 2006. Physiological Changes and Defense Mechanisme Induced by Cadmium Stress in Maize. Review article. J. Plant. Nutr. Soil Sci, Vol 159: 230-246, 2006.

Patrick, L. 2003 Toxic Metals and Antioxidants. Part II the Role of Antioxidant in Arsenic and Cadmium Toxicity-Toxic Metals Part II. Alternativer Medicine Review. May, 2003.

Piyatiratitivorakul, P \& Boonchamoi, P. 2008. Comparative Toxicity of Mercury and Cadmium to the Juvenile Freshwater Snail, Filopaludina martensi martensi. Science Asia 34 (2008): 367370. www.scienceasia.org
Rico, L.G., Felix, C.F., Burguenso, R.R., and Marini, M.J. 2002. Determination of cadmium and zinc and its relathionship to metalloghionein level in swine kidney. Rev. In. Contant Ambient, Vol 18 (4): 157-162, 2002.

Roccheri, M.C., Agnello, M., Bonaventura, R., and Matranga. 2004. Cadmiun induces the Expression of Specific Stress Proteins in Sea Urchin Embryos. Elsevier. (online). www.elsevier.com. Diakses 4 September 2010.

Rochyatun, E., and Rozak, A. 2007. Pemantauan Kadar Logam Berat dalam Sedimen di Perairan Teluk Jakarta. Makara Sains, Vol 11 (1), April 2007.

Russo, R., Bonaventura, R., Zito, F., Schroder, H., Muller, I., Muller, W.E.G., and Matranga, V. 2003. Stress to Cadmium Monitored by Metallothionein Gene Induction in Paracentrotus lividus Embryos. Cell Stress \& Chaperones, Vol 8 (3): 232-231.

Schoettger, R.A. 1996. Problems of Aquatic Toxicology, Biotesting and Water Quality Management. Proceedings of USA-Rusia Symposium, Borok, Jaroslavl Oblast. Juli 21-23 1996. Published by Ecosytems Research Division Athens.

Schutzendubel, A., Schwanz, P., Teichmann, T., Gross, K., Langenfeld-Heyser, R., Godbold, D.L., and Polle, A. 2001. Cadmium-Induced Changes in Antioxidative 
Systems, Hydrogen Peroxide Content, and Differentiation in Scots Pine Roots1. Plant Physiology, Vol 127: 887-898, November 2001. www.plantphysiol.org

Schutzendubel, A \& Polle, A. 2002. Plant Responses to Abiotic Stresses: Heavy Metal-Induced Oxidative Stress and Protection by Mycorrhization. Journal of Experimental Botany. Vol. 53, No. 372.

Shah, S.L. 2005. Effects of Heavy Metal Accumulation on the 96-h $\mathrm{LC}_{50}$ Values in Tech Tinca tinca. L., 1758. Research Article. Turk. J. Vet. Anim Sci, Vol 29: 139-144, 2005.

Sharma, S \& Prasad, F.M. 2010. Accumulation of Lead and Cadmium in Soil and Vegetable Crops Along Major Highways in Agra (India). E-Journal of Chemystry, Vol 7(4): 11741183, 2010.

Smiri, M., Chaoui, A., \& Ferjani, E.E. 2010. Interaction between Heavy Metals and Thiol-Linked Redox Reactions in Germination. Pakistan Journal of Biological Sciences, Vol 13 (18): 877-883, 2010.

Sobolev, D and Begonia, M.F.T. 2008. Effects of Heavy Metal Contamination upon Soil Microbes: Lead-induced Changes in General and Denitrifying Microbial Communities as Evidenced by Molecular Markers. Int. J. Environ. Res. Public Health, Vol 5(5) 450-456, 2008.
Soualili, D., Dubois, P., Gosselin, P., Pernet, P., and Guillou, M. 2007. Assessment of Seawater Pollution by Heavy Metals in the Neighbourhood of Algiers: use of sea urchin, Paracentrotus lividus, as Bioindicator. Email: mgluillou@univ-brest.fr.

Diakses 8 September 2010.

Temara, A., Skei J.M., Gillan, D., Warnau, M., Jangoux, M., and Dubois, P. 1998. Validation of the Asteroid Asterias rubens (Echinodermata) as a Bioindicator of Spatial and Temporean Trends of $\mathrm{Pb}, \mathrm{Cd}$, and $\mathrm{Zn}$ Contamination in the Field. Elsevier. Marine Enviromental Research, Vol 45 (4/5): 341-356, 1998.

Valko, M., Morris, H \& Cronin, M.T.D. 2005. Metals, Toxicity and Oxidative Stress. Current Medicinal Chemistry, Vol 20: 1161-1200, 2005.

Vinodhini, R \& Narayanan, M. 2008. The Impact of Toxic Heavy Metals on the Hematological Parameters in Common Carp (Cyprinus carpio L.). Iran. J. Environ. Health. Sci. Eng., Vol 6 (1): 23-28, 2009.

Vinodhini, R., and Narayanan, M. 2008. Bioaccumulation of Heavy Metals in Organs of Fresh Water Fish Cyprinus carpio (Common carp). Int. J. Environ. Sci. Tech, Vol 5 (2): 179-182. 2008.

Warlina, L. 2004. Pencemaran Air: Sumber, Dampak dan Penanggulangannya. Makalah Pengantar Ke Falsafah Sains. 
Bogor: Program Pascasarjana Institut Pertanian Bogor.

Yokouchi, M,. Hiramatsu, N., Hakayawa, R., Kasal, A., Takano, Y., Yao, J., dan Kitamura, M. 2007. Atypical, Bidirection Regulation of Cadmium-Induced Apoptosis via Disctinct Siganaling of Unfolded Protein Response. Cell Death and Differentiation, Vol 14: 1467-1474, 2007.

Yon, S., Han, S.S., and Rana, S.V.S. 2008. Molecular Markers of Heavy Metal Toxicity- A New Paradigma for HEALTH RISK ASSESSMENT. Journal of Environmental Biology., Vol 29 (1): 1-14, January 2008.

Yi, L., Hong, Y., Wang, D., and Zhu, Y. 2007. Determination of Free Heavy Metal Ion Concentrations in Soils Around a Cadmium Rich Zinc Deposit. Geochemical Journal, Vol 41: 235-240, 2007.

Zangger, K, Oz, G., Otvos, J.D., and Armitage, I.M. 1999. ThreeDimensional Solutions Structure of Mouse $\left(\mathrm{Cd}_{7}\right)$-metallothionein1 by Homonuclear and Heteronuclear NMR Spectroscopy. Protein Science, Vol 8: 6230-2638, 1999.

Zangger, K., Oz, G., Haslinger, E., Kuner, O., and Armitage, I.M. 2001. Nitric Oxide Selectively Releases Metals from NTerminal Domain of Metallothioneins: Potential Role at Inflamatory Sites. The FASEB Journal, Vol 10:1096. Published Online March 20, 2001.

Zauke, G.P. 2008. Toxicokinetic Models as Predictive Tool in Biomonitoring of Metal in Zooplankton: A Systesis of Ideas. Hydrobiologia, Vol 614: 3-18.

Zhou, Q., Zhang, J., Fu, J., Shi, J., and Jiang, G. 2008. Biomonitoring: An Appealing Tool for Assessment of Metal Pollution in the Aquatic Ecosystem. Review. Elsevier. (online). www.elsevier.com. Diakses 10 September

2010. 